\title{
Politics of the green economy in Russia's European North
}

\author{
Vladislava Vladimirova $^{1}$ \\ Uppsala University, Sweden
}

\begin{abstract}
The global drive for a greener economy generates controversy in Russia, a country that is dependent on export of raw mineral resources. Debates are most heated in relation to the North, where resource extraction takes place. In an environment of high unemployment and low income ecological issues are priority for a few environmentalists. Russian politicians, who support the green economy in international fora, instead emphasize economic development at home and show little interest in environmental protection. This article focuses on the controversies over policies from the perspective of environmentalists and members of local communities in Murmansk Region who are struggling to establish a national park in the Khibiny Mountains. The initiative has been presented by some environmentalists as a contribution to the green economy, but it also demonstrates mechanisms of nature governance in Russia, as well as the limited possibilities for bottom-up participation of NGOs, scholars, and the indigenous community. The article also situates the green economy in Russia within critical analysis of the global green economy, which reveals common trends and problems. Russia replicates the common overemphasis on economic development and commoditization of nature rather than radical reformation of nature's value and use.
\end{abstract}

Key words: Green Economy, Russia, Nature Conservation, Arctic, Indigenous Sami, Murmansk Region

\section{Résumé}

La poussée mondiale pour une économie plus verte génère la controverse en Russie, un pays qui dépend de l'exportation de ressources minérales brutes. Les débats sont les plus intenses par rapport à l'Arctique au nord du pays, où se déroule la majeure partie de l'extraction des ressources. Dans un contexte de chômage élevé et de faible revenu, les questions écologiques sont prioritaires pour quelques environnementalistes. Les politiciens russes, qui soutiennent l'économie verte dans les forums internationaux, insistent plutôt sur le développement économique lorsqu'ils parlent aux Russes et montrent peu d'intérêt pour la protection de l'environnement. Cet article se concentre sur les controverses sur les politiques dans la perspective des écologistes et des membres des communautés locales dans la région de Murmansk, qui luttent pour établir un parc national dans les montagnes de Khibiny. L'initiative a été présentée par certains environnementalistes comme une contribution à l'économie verte, mais la campagne démontre également des mécanismes de gouvernance de la nature en Russie. Les ONG, les universitaires et la communauté autochtone ont peu de possibilités de participer à la base. L'article situe également l'économie verte en Russie dans une analyse critique de l'économie verte mondiale, qui révèle des tendances et des problèmes communs. La Russie réplique l'accent trop répandu sur le développement économique et la marchandisation de la nature plutôt que la réforme radicale de la valeur et de l'utilisation de la nature.

Mots clés: Économie verte, Russie, conservation de la nature, Arctique, Sami indigène, région de Murmansk

1 Dr. Vladislava Vladimirova, Lecturer, Centre for Russian and Eurasian Studies and Depatment of Cultural Anthropology and Erhnology, Uppsala University, Sweden. Email: vladislava.vladimirova "at" ucrs.uu.se. Acknowledgements: Research has been supported by the programs INPOINT, Socioeconomic significance of developmental projects in Northwest Russia: the insiders' point of view, funded by the Norwegian Research Council, and CLUE, Dynamics of Circumpolar land use and ethnology, funded by the American National Science Foundation. I am grateful to the editors of this Special Section, specifically to Tor Benjaminsen. I am indebted to two anonymous reviewers who helped greatly and made me see my argument from a new perspective. My thanks go to Hugh Beach and Yulian Konstantinov for comments and discussion during the process of writing, and especially to Nathan Light who contributed significantly to the logical coherence and language of the article. This is the fifth article in Connor Cavanagh and Tor Benjaminsen (eds.) 2017. "Political ecologies of the green economy", Special Section of the Journal of Political Ecology, 24:200-341. 


\section{Resumen}

El impulso global por una economía más verde, ha generado controversia en Rusia, un país dependiente de las exportaciones de los recursos de minerales. Los debates relacionados con la zona norte, son los más intensos, ya que es ahí donde la extracción se lleva a cabo. En un ambiente de alto desempleo y bajos ingresos, los asuntos ecológicos son prioridad para apenas unos cuantos ambientalistas. Los políticos rusos, quienes apoyan la economía verde a nivel internacional, apoyan en cambio el desarrollo económico doméstico y muestran muy poco interés en la protección ambiental. Este artículo se enfoca en las controversias en las políticas desde la perspectiva de los ambientalistas y comunidades locales de la región de Murmansk, la cual tiene conflictos para establecer un parque nacional en las montañas de Khibiny. La iniciativa ha sido presentada por algunos ambientalistas a manera de contribución para la economía verde, pero también es una muestra de los mecanismos de gobierno de la naturaleza en Rusia, así como de las limitadas posibilidades de participación ascendente por parte de ONGs, académicos y comunidades indígenas. El artículo también sitúa la economía verde en Rusia dentro de un análisis crítico de la economía verde global, lo cual revela corrientes y problemas comunes. Rusia replica una común exageración en el énfasis en el desarrollo económico y la mercantilización de la naturaleza en lugar de una reforma radical del valor y uso de la naturaleza.

Palabras clave: economía verde, Rusia, Conservación de la naturaleza, Ártico, indígenas Sami, Región Murmansk

\section{Introduction}

This article critically analyzes the green economy by engaging with empirical data from Circumpolar Russia, a region that has so far received limited attention. The study contributes to knowledge about the social and economic dimensions of the green economy in an Arctic context, an important area given the increasing effects that rapid climate change has on the Arctic environment, accompanied by increasing resource exploitation (Andreassen 2016).

The article analyzes the complex political and social dynamics around the green economy in Russia. Russian experts, in contrast to the majority of green economy ideologists, are skeptical about market-based solutions, such as private investment or natural capital, to address environmental degradation. Instead, they emphasize centralized state regulation of natural resource extraction and energy production, and state investment and support to renewable resource use and technological innovation (Kuzhelev 2014; Onishchenko 2014; Rodionova and Lipina 2015). Russian researchers view the state's use of the green economy as providing a space and language for engagement with international politics (Zakharova 2015). In this article, however, I will analyze an empirical case which shows that the green economy, to a lesser degree, is also becoming an arena for national politics, mostly by providing symbolic space for negotiation by ordinary residents and civil-society groups with regional administrations.

In an environment of high unemployment and low income, and insufficient social security provisions, agitation around ecological problems in Russia has diminished since the 1990s (Müller 2014; Pakhomova, Rikhter, and Malyshkov 2013; Zakharova 2015). In 2009, a UNEP-conducted evaluation of the ecological provisions in national anti-crisis programs using global indicators, assessed Russia at 0\%, against a global average index of $15.6 \%$ (Kravchenko 2009). Russian politicians see the language of modernization as more powerful than the green economy discourse. Governance of nature, on the other hand, is moved by complex configurations of private economic interests among elites and the public sphere. The tenacity of Soviet ideas and values of public participation and responsibility, reinforced by foreign initiatives for building civil society in Russia, carves out a small space for bottom-up influence (Henry 2010). This article will look at the intersection between Russian green economy discourse within the international arena, how the green economy has been presented to the Russian public, and finally how difficult it is to operationalize it from below. 
I introduce the initiative of ecologists and environmentalists to establish the Khibiny Mountain and ski tourism site as a National Park in order to protect it from advancing mineral extraction, logging, and unregulated tourism. This attempt at developing sustainable tourism simultaneously with nature conservation reveals the bureaucratic and economic hindrances to green economic development. Analysis of public debates around the Khibiny project involving organizers, extractive businesses, regional and federal administrators, and local residents, reveals mechanisms of nature governance in the Russian North. The position of the indigenous Sami is also important to the narrative since they are a stake-holder and a political actor within Northern land-use. They have a well-established political movement, but a limited ability to unite in pursuit of common interests in nature resources.

I start with critical points that analysts have raised toward the global green economy that are of most relevance to the discussion here: how the green economy discourse is instrumental in reproducing unequal relations of power and economy under neoliberal capitalist domination. Further, the political implications of increased privatization and commoditization of nature in conservation practices are briefly examined. This introduction helps then to connect international trends to the debate over the green economy in Russia. How do Russian scholars interpret and deflect the dominant green economy ideas so that the latter make sense in the Russian social, economic, and political context?

The Khibiny National Park project first attracted my attention as a rare instance in Circumpolar Russia of green economy discussions, and in particular its use by local civil-society organizations in a political debate. Nature conservation had lost its previous standing in the space of post-socialist reforms, and its decaying status is detectable even in domestic green economy discussions which often overlook it as a realm for greening. Nevertheless, environmental activists mobilized the concept as symbolic capital in the unequal struggle with extractive businesses and the regional authorities who favor the latter. Politicians and ideologues also orient the economic priorities of the country towards extractive industries, for which the North is of great strategic importance. Hence, this article argues that the green economy in the Russian Arctic has been metaphorically subsumed under the idiom of mastering nature. Thus it has limited power to act as conceptual advocacy (Niezen 2010). The article will discuss the bureaucratic power games that are opposed to the Khibiny project and that hinder its realization. While the green economy does not have adequate foundations in Russia to contribute to the commoditization of nature conservation, its rhetoric is spreading in the North. Such vocabulary plays a performative role and helps promote ideologies of neoliberal conservation, even though the latter conflict with inherited Russian ideas that see protected areas as pristine nature, reserved for scientific exploration. A short introduction to Russian traditions of nature conservation substantiates this argument.

In the final discussion, I connect the empirical study of the Khibiny Park to critical analysis of the global green economy, and its project of commoditizing nature. In this broader framework, the case of Khibiny is revealing in many ways. First, it shows that the Russian authorities pick up some of the green economy rhetoric as a governmentality technique. Second, it provides a micro-level picture of some technologies of power for increasing economic and political inequality and discrimination. Third, it demonstrates the failure of the green economy to serve environmentalists, and to generate bottom-up empowerment. In this sense, the green economy paradigm fails to provide the positive potentials envisioned. I finish with a question that requires further research: does accepting and normalizing neoliberal notions and values in a conservation project popularize capitalist ontologies and morality, making people more tolerant and willing to go along with the present Russian economic and political model, and resulting eventually in replacing the memory of the Soviet collectivist social and economic model?

Empirical research for the article employed anthropological methods, such as semi-structured interviews, participant observation, and work with published sources, including legal and archival documents, and media reports. Online social forums have been used too, mostly the website of the National Park Khibiny and the public Facebook group 'Movement for Defense of Khibiny.' My research in this region of the Russian North has its beginnings in 2001, but I can't say exactly when Khibiny Park, and nature conservation in general came to my focus. Intensive field research on the topic was conducted during a one 
month trip in September 2014. The latest online publications addressed in the article are from November 2016. My broader interest in post-socialist transformation in the Russian Arctic, with particular interest in indigenous people and land use, is reflected in the article.

\section{Nature conservation debates in the green economy}

The concept of the green economy has gained huge popularity in relation to the several concurrent crises of the last decade: climate, biodiversity, fuel, food, water, and more recently, the global financial system:

In its simplest expression, a green economy is low-carbon, resource efficient, and socially inclusive. In a green economy, growth in income and employment are driven by public and private investments that reduce carbon emissions and pollution, enhance energy and resource efficiency, and prevent the loss of biodiversity and ecosystem services. (UNEP 2011: 16)

Even though the concept has been in circulation for a few decades, its current ubiquity results from being chosen as a central theme for the United Nations' 2012 Conference on Sustainable Development (Rio+20), "as a means for catalyzing renewed national policy development and international cooperation and support for sustainable development" (Caprotti and Bailey 2014: 195; Allen and Clouth 2012: 5; Brown et al. 2014).

The green economy has produced a broad debate among political ecologists. The emphasis on economic growth, allegedly as a means for social justice and more fair distribution of resources, has been condemned as an attempt to use the ecological crisis in order to solve "other problems contemporary capitalism is facing, such as the economic crisis and the crisis of legitimacy" (Kenis and Lievens 2015: 231; Ferguson 2015). In this sense, the green economy is seen as a mere "intensification of existing policy directions under neoliberalized environmental governance" (Brown et al. 2014: 248; Arsel and Büscher 2012; Finley-Brook 2007; Wanner 2015).

The belief that a green industrial revolution is on the way (Jänicke and Jacob 2009; Stern and Rydge 2012) and a global technocratic policy propaganda that argues environmental and social problems are amenable to technological fixes, have been described as naïve, overlooking the complexity of social processes that trigger inequality and ecological crises (Brown et al. 2014; Caprotti 2012; Death 2014; KnoxHayes and Hayes 2014). The impacts of neoliberal environmental governance and nature conservation strategies that the green economy reinforces, have been condemned as deepening unequal power relations through maldistribution of access to resources (Arsel and Büscher 2012; Brockington and Duffy 2010; Brown et al. 2014: 248; Castree 2008; Fletcher 2010, 2012; Himley 2008; McAfee 2012). Neoliberalization of nature conservation, as Fletcher defines it, implies the promotion of:

1) capitalist markets for natural resource exchange and consumption; 2) privatization of resource control within these markets; 3) commoditization of resources so that they can be traded within markets; 4) withdrawal of direct government intervention from market transactions; and 5) decentralization of resource governance to local authorities and non-state actors such as non-governmental organizations (NGOs). (Fletcher 2010: 172)

As Jim Igoe and Dan Brockington warn, neoliberal nature conservation provides means for control and profit to national and international elites while excluding local and indigenous inhabitants (Brockington and Duffy 2010; Brockington and Igoe 2006, 2007; Schmidt-Soltau and Brockington 2007).

Scholars recognize that the expectation to generate investment and income to and from nature conservation through cooperation with private business and entrepreneurship is risky, and elusive (Brown et al. 2014, 253). In a recent study, "for-profit biodiversity conservation" - financed through private investment and undertaken with the aim of generating profitable returns for investors, is shown to be geographically 
constrained, with environmental market rhetoric and exaggerated importance (Dempsey and Suarez 2016). There are business enterprises like eco-tourism, bioprospecting, and payment for environmental services undertaken to commoditize in situ natural resources and create a market for their exchange (Büscher, Dressler, and Fletcher 2014; West 2006). These had raised a wave of critical responses prior to the spread of the green economy paradigm. Ecotourism has been shown to transform communities and their socioecological landscapes by introducing new forms and ideas of nature and land use rights, dependencies, and boundaries (Duffy 2010; West, Igoe, and Brockington 2006). It has reinforced social class and regional divisions, economic segregation, and unequal distribution of profit, only a small part of which remains locally (Krüger 2005). Paradoxically, ecotourism can lead to higher pressure on local resources because it increases the number of tourists and activities (Panusittikorn and Prato 2001), as well as more stakeholders, resulting in damage to the environment and its residents (Carrier and Macleod 2005). As Fletcher and others show, without adequate state regulation, corporate business actors are more successful in defending their interests when conflicts between industrial exploitation and biodiversity conservation occur (Castree 2008). Instead of supporting local community interests and their natural environment, neoliberalisation creates more space for activity by corporations and international agencies who may even take over resource management through de-centralized governance structures (Fletcher 2010; Levine 2002).

As Jessica Dempsey and Daniel Chiu Suarez argue, "selling nature to save it" though limited, produces significant outcomes. It reaffirms non-political explanations of biodiversity loss, and reinforces neoliberal rationalities among conservationists, thus distracting public attention from real problems and discrediting alternative approaches to reforming environmental protection policies. They call this effect political performativity, and argue that it cultivates neoliberal subjectivities among conservationists and society (Dempsey and Suarez 2016: 665-667). They are not alone in exploring the production of neoliberal conservation ideology through governmentality, concealment, assembling facts and spectacles, and scientific justification. These justify, spread, and normalize neoliberalism across society (Büscher et al. 2012; Sullivan and Hannis 2014; Sullivan 2013a).

Neoliberal conservation can make nature and experience of it into commodities, with value calculated on the basis of consumption by visitors and other economic use values (Alexander 2000; Duffy 2013, 2015; West, Igoe, and Brockington 2006). Commoditization transforms local values and meanings ascribed to nature, along with its ontological realities, through a complex and dramatic process which Sian Sullivan has tried to capture in the phrase "cultural displacement" (Sullivan 2009: 24; 2006; see also Tsing 2003; West, Igoe, and Brockington 2006; West 2006). Other critiques point out the myriad ways neoliberal nature conservation produces an essentialized idea of human behavior as self-interested and rational, responding first and foremost to economic incentives (Büscher et al. 2012; Sullivan 2006). These critiques point to ways that particular subjectivities are being cultivated and spread widely in order to remake places and societies in ways that are compatible with capitalist economy, society, and values (Fletcher 2010: 176; Igoe 2010; Sullivan 2013b).

Critical and post-structural accounts of neoliberal nature management as (global) eco-governmentality (Goldman 2001), or neo-liberal environmentality (Shear 2014), join voices with other strands of analysis, departing from Marxism-inspired frameworks. Thomas Wanner draws upon the Austrian-Hungarian economist Karl Polanyi's view that the economy is unavoidably embedded in social relations, and that nature is a "fictitious commodity", i.e. one that has intrinsic value for human life which exceeds the value that the market can put on it. Thus, he argues that to attribute the solution of the environmental crisis to what actually is the main cause behind it, i.e. the market economy, sounds naïve at the least (Wanner 2015, 31). Employing the analytical framework of Gramsci, and more specifically his notion of passive revolution, Wanner claims that sustainable development only diverts attention from the "the counter-hegemonic challenge of environmentalism" and thus is "part of the sustainable development of capitalism" (Wanner 2015: 27). Passive revolution, as Gramsci explains, occurs when "a counter hegemonic ideology in civil society wins a war of position, that is the ideological struggle with the hegemonic ideology" (Gramsci 1971: 366; Wanner 2015: 25). In this context, green economy and growth constitute the next passive revolution, a step further in 
maintaining the "techno-economic hegemony" and consumer capitalism through the prospects of "decoupling" of economic growth from natural resource use and environmental degradation. Decoupling, Wanner argues, helps strengthen the market economy in the face of environmental risks, but does not preserve the environment (Wanner 2015: 27-28).

Wanner emphasizes that the green economy still can be a useful tool and incentive, if treated critically, for empowerment of civil society through political activism. Civil society's strong involvement, as provided in the green economy documents, is a necessary condition for efficiency. Civil society's role, however, is in developing "a consciousness of contradictions" through constant vigilance and challenging popular beliefs, and "common sense" (Wanner 2015: 36). The struggle over meaning, Wanner suggests, following Goldman (1998) takes place in the intersection between global and regional/local levels and bottom up movements and economic/state institutions. This article looks precisely at this intersection between the international, national, and local levels in Russia, where the green economy acquires meaning(s) and produces practices.

\section{Green growth and modernization in Russia}

The Assessment of Assessments of Europe's environment emphasizes that green economy principles in different states give differing weights to the areas of action specified by the UNEP and other relevant programs (Environment 2011: 113-114; Rodionova and Lipina 2015; Zakharova 2015). As expected, energy and fossil fuel resource governance appear to be the central concern in Russia, where the energy sector is the foundation of the economy, but also the major cause of environmental degradation (Environment 2011: 113114; Kuzhelev 2014). Russian scholars, at the same time, critically discuss the economic and political model of the country. As long as the national economy is based on intensive extraction and export of raw natural resources, and political power is dependent on the extractive industry elites, known as oligarchs, mechanisms prescribed by international organizations or national experts are not likely to contribute to "greening" the Russian economy (Danilenko 2013; Zakharova 2015). Some scholars even talk of a "highly specific state ecology, namely "ecology of the pipe", that involves material, financial, and human resources with the purpose of strengthening the ruling elite, because "the pipes demand an increasing number of managers, engineers, construction workers, and most of all guards, that are loyal to the regime" (Ianickii 2010: 14). Others have called this model "the policy of double standards" (Danilenko 2013: 45).

Russian legislation and administrative practices in the sphere of the green economy, as well as investment policies and economic stimuli remain underdeveloped (Gushchina and Badrak 2013), which actively favors non-renewably resource-based production (Zakharova 2015). Corruption and the powerful lobby of extractive industry contribute strongly to such trends (Anufriev, Anufrieva, and Petrun'ko 2014). Green economy principles contradict and are perceived as a threat to the interests of the traditional energy sector and consequently to the state policy that stands behind it (Gushchina and Badrak 2013). The current energy inefficiency of the country wastes an amount equal to the annual consumption of France (Centre 2011). In their effort to help work out strategies for Russia's green economy, experts accordingly tend to focus on the fossil fuel and energy sector, while other areas, such as sustainable agricultural production, nature conservation and management, receive little attention. Ecosystem protection and effective management, if included, is usually the last area of concern for discussions of greening the economy (Lavrikova and Malysh 2014).

UNEP's advisory services to the Russian Federation states that thanks to its natural resources and current economic growth, Russia has "a favorable opportunity" to even "take a leadership role" in the global process of greening the economy (UNEP 2011). UNEP signed a contract with Russia in April 2013 with the aim of greening the Olympic Games in Sochi and addressing environmental challenges in the Arctic. It is perhaps interesting to note that Russia has been not only a partner but a donor to UNEP, and that in 2013 and 2014 its contribution to the Environment Fund amounts to US\$1.5 million (Nuttall 2013). As scholars note, Russian political leaders willingly participate in international forums and meetings within the BRICS alliance 
and at RIO+20, where they state their intention to carry out a green economy transition. Russia has also signed more than one hundred international conventions, agreements, and resolutions (Zakharova 2015).

At the same time the green economy, as a concept, as politics, and as a set of prescribed practices, receives little attention inside the country (Zakharova 2015). Russia sits in very low positions in international surveys and rankings of environmental policy (Kravchenko 2009). Local scholars explain this as resulting from economic crisis, which diverted efforts elsewhere. In general, the lack of financial and economic resources to pursue ecological projects is noticeable throughout the country. At the same time, such explanatory rhetoric in its turn favors the disengagement of many political and business stakeholders, including financial ones (Pakhomova, Rikhter, and Malyshkov 2013: 119).

Two concepts come to summarize the green economy ideology in Russia: green growth and modernization. While this is based in international green growth discourse to some extent, the neglect of some dimensions of the green economy, such as nature conservation, is notable. Green growth appears in Russia's government-commissioned report from 2012, Strategy 2020: new growth model - new social policy (Porfiriev 2013: 3). The document's aim is restructuring the Russian economy, and it tackles green growth in the subsection about environmental protection and ecological security (pp. 421-423). The main stress is on the principle of "double benefit", in which solving socio-economic problems is accompanied by a positive environmental effect. The report states that a gradual expansion of environmental policy in the development of other sectors, especially in the energy sector, should be undertaken. "We must start with "greening" our economic development planning for the future" (Mau and Kuz'minova 2013: 421). This formulation certainly postpones such action to after the period of the report (after 2020). Further on, in the three pages of the subsection on environmental protection, some necessary measures harmonious with the aims of the green economy are mentioned, but vaguely and without provisions for specific actions (Mau and Kuz'minova 2013).

The leader of the Russian delegation to the RIO+20 United Nations Conference on Sustainable Development in June 2012, D. Medvedev, is reported to have said that:

A new paradigm of development is needed, one which is able to provide social welfare without too much pressure on the environment. Interests of the economy, on the one hand, and conservation of nature, on the other hand, should be balanced and should focus on the long term". (Stepanov 2012)

A Russian scholar interpreted this statement as launching the idea of parallel growth:

....economic growth, energy efficiency and "green" economy which exacerbate the problem of modernization in the country. It's not just about the technical and technological modernization in the usual sense in which the phenomenon seems to be discussed in the public media, but at different levels of government, namely, the socio-economic, and civilizational. (Stepanov 2012: 26).

As this analysis indicates, the green economy gets subsumed under the Russian national project of modernization. Modernization was announced in 2010 by the then president Medvedev as part of Russia's goal of becoming a country where "well-being and the quality of life of citizens will be assured, not only through export of raw materials, but also through the use of its intellectual resources" (REGNUM 2010). This rhetoric, which can be seen as the predecessor of Strategy 2020, sends strong messages to the regional administrations, where economic growth becomes justifiable as their main target. On the way to the regional administrations, however, few of the accompanying objectives of greening receive attention or become implemented. 
Nature conservation has generally been neglected in academic analysis of the green economy in Russia. Nor is it included in any of the priority areas for greening listed by analysts. Although it is listed as a green concern, it has received no further attention. Nevertheless, as the Khibiny Park project shows, public opinion, at least in some environmentalist circles, perhaps connects the green economy with nature conservation, and most clearly with sustainable development. This points to a public perception, even though without much popularity, that conservation is part of the green economy paradigm in Russia, at least on a symbolic level (Favorskaia 2008; Lagunina 2008; Likhachev 2008).

In Russia, strong forces prevent the efficient political participation of civil society on which the green economy relies. Realizing this, local scholars argue that the state alone should stand behind developing the necessary legal, political, administrative and economic resources necessary for greening the economy (Kuzhelev 2014; Zakharova 2015). It is obligatory for the efficiency of any greening initiative that the ecological policy of the state is reformed (Danilenko 2013). In the contemporary phase of market economy, Russian analysts contend, it is the state's function to benchmark, or create exemplary models for other economic actors. State economic enterprises serve as a model, according to which private economic actors adapt, thus creating a common institutional environment. In this context, the ecological practices of staterelated organizations have a leading role, but unfortunately this has largely been negative. Those businesses who present their interests as state interests are also the most successful ones in blocking the observance of international and national ecological standards (Shvarts and Knizhnikov 2012).

\section{An agenda for protection or for mastering the Arctic?}

The Arctic agenda has been given central focus at many international forums in the context of rapid climate change (Sörlin 2013), which threatens the region while simultaneously increasing access to the extraction of fossil fuel and other non-renewable resources. Murmansk Region, the location of this study, is still treated as a periphery, or even 'frontier.' This is despite being discussed in international and national settings as having great geopolitical centrality. In the national (mental) map, such areas are mostly important for their natural resources that, after extraction, get transported to and provide revenues for the centers of the state, i.e. Moscow and St. Petersburg. They yield greater profits if shipped abroad, where the biggest part of the marketing cycle takes place (Vitebsky nd). Russia's imperial and Soviet histories left their legacies in the construction of such a complex resource map (Ssorin-Chaikov 2003; Slezkine 1994). This said, one should not ignore the massive industrial development and urbanization of the North, as well as labor migration that took place there in Soviet times. Since fur trading started bringing profit to the Russian Empire in the $16^{\text {th }}$ century, the Arctic was a strategically important zone for state security - long before the famous militarization during the Cold War (Forsyth 1994). Currently, 90\% of Russia's natural gas comes from the Arctic and Subarctic regions (Novikova 2014).

Russia is one of the great powers in international Arctic cooperation, in which solutions to environmental problems and promotion of sustainable development have been one of the platforms. The higher level of accumulation of environmental pollution in the Arctic and the fact that Russia stands behind at least two thirds of it, single out environmental degradation and conservation as priority areas (Stokke, Hønneland, and Schei 2006). At the same time, the vigorous discussion and planning of activities characteristic of the dawn of Arctic cooperation in the early 1990s largely dissipated later on, because of the lack of funding for joint projects, as well as disagreements regarding the outcomes of such work. Part of the problem was in the asymmetry of environmental cooperation; Russia was mostly a recipient of financial resources, expertise, technologies and advice (Hønneland 2003; Stokke, Hønneland, and Schei 2006). In the political situation since the second half of the 2000s this configuration has been raising discomfort on both sides, in terms of material resources and of symbolic meaning. While Russia's image as environmental hazard (Hønneland 2003) has not faded, issues like its military ambitions have come to the forefront of international politics (Øverland 2010; Wilson Rowe and Blakkisrud 2014; Wilson Rowe 2013). The positive long term result from the earlier phase of Arctic environmental cooperation has been the establishment of informal 
channels of exchange between Russian and international green movements and activists, which play an important role in the development of a bottom-up political process in Russia (Henry 2010; Stokke, Hønneland, and Schei 2006).

UNEP has also been designated as the Program Coordination Agency for the Arctic Agenda 2020, a Russian-government project, co-funded by the Global Environment Facility and the Russian Federation, for protecting the Arctic region (Nuttall 2013). The Program, launched in 2011, aims to develop a longer term Program on sustainable environmental management in the Russian Arctic under rapidly changing climate. The initiative addresses energy efficiency, renewable energy development, protected areas, and transboundary marine systems, among other issues. One goal is to facilitate the implementation of the Strategic action program for protection of the environment of the Arctic Zone of the Russian Federation (SAP-Arctic), prepared under the auspices of the UNEP/Global Environment Facility project Russian Federation - support to the national program of action for the protection of the arctic marine environment (NPA-Arctic) with the Russian Ministry of Economic Development (Facility 2009). SAP-Arctic "is directed to preserve and protect the environment and to eliminate negative impacts from economic and other activities", while taking into consideration the interests of the local population, including indigenous people (Federation and UNEP/GEF 2009).

The spirit of this document which supports the green economy does not extend very much into the Russian domestic Strategy for Arctic development, the latest legislative document, signed by Putin in 2013. That strategy pays attention first and foremost to the economic exploitation of the region, promoting a vision of the Arctic as "an enormous storage of carbon fuels" that people can extract and process through large scale investment projects in order to insure the wellbeing of the whole country (Dmitriev 2013). The strategy primarily tackles the expansion of oil and mineral resource extraction; support to scientific exploration in service of the latter; improvement of the transport and communication systems, and militarization serving the aims of national security in the region. The program also stresses increasing the standard of living in the Arctic (Strategy 2013). The rhetoric and spirit of the document, as reflected in the Russian media, indicates a strategy for economic development, modernization, and "mastering" of the North, as captured by the Russian concept of "osvoenie 2 ", used in the document. Environmental security is also listed as one of the strategic areas of development, with suggested scientific, ecological, and economic innovation that would enable security of nature in the context of the future planned intensification of economic exploitation (Andreassen 2016). A few entries in the section promise increased number of protected areas (Strategy 2013). Overall, the strategy foresees heavy industrial development and "mastering of nature" as the future priorities in the Arctic, which at the present level of social and technological development is not promising much greening.

A further provision of this document, reflecting a new emphasis in Russian political discourse, is described as "state-private partnership." State authorities carry the main responsibility for its realization by commercial enterprises, NGOs, and civil society, which are supposed to support and cooperate with its initiatives. While the effects of the recently launched policy, more widely known in international practice as "public-private partnership," are still unclear on the ground in Russia (Belitskaya nd), it appears to emphasize the primacy of private business interests. Big investors and companies in Russia that aggressively pursue their economic interests are able to attract the support of regional authorities. Study of the Khibiny Park project illustrates the bureaucratic hindrances that public organizations and environmental activists face when trying to exercise their legal and civil rights if they are in conflict with industrial company interests.

\section{Green development in Murmansk Region}

Murmansk Region is a heavily urbanized and industrialized area of the Russian Arctic, with strong dependence on mining. The Soviet economy, together with patronizing politics toward the indigenous

\footnotetext{
${ }^{2}$ Osvoenie is a major metaphor of Soviet modernization and economic development. In relation to nature, it implies human control through scientific discovery and engineering. An apogee of osvoenie has been Soviet projects to change the flow of rivers, see for example Richter (1997).
} 
residents of the region, has transformed the Kola Peninsula politically, socially and economically (Figure 1). In whatever terms we qualify such changes, whether as colonization, domination over indigenous populations, or development and progress, they are a reality that many generations of people of different and often mixed ethnic and cultural origin have lived with and accept more or less as normal. Air transport and extensive logistic support, roads or railways, no doubt disruptive of previously existing ecosystems and human-nature relations, have become a given and a necessity, that everyone expects state authorities to maintain. Enforced collectivization of traditional subsistence economies such as reindeer herding and fishing brought a number of changes in subsistence and residence patterns.

What followed after perestroika (mid 1980s to early 1990s) can hardly be described as a turn toward tradition, or as any kind of improvement. Many indigenous economic enterprises (like reindeer cooperatives), as well as other industries went into crisis or failed, deprived of state regulation and financial support. At the same time, indigenous groups in the North experienced previously unseen political and cultural revivals, taking models and support from the worldwide indigenous movement. Cross border connections were key in this process, with mobility and political alliances across borders, as well as the formation of international identities and solidarity. The Nordic pan-Sami movement and its relationship with and influence over the small group of Sami in Murmansk region provide good examples (Øverland and Berg-Nordlie 2012; Vladimirova 2012).

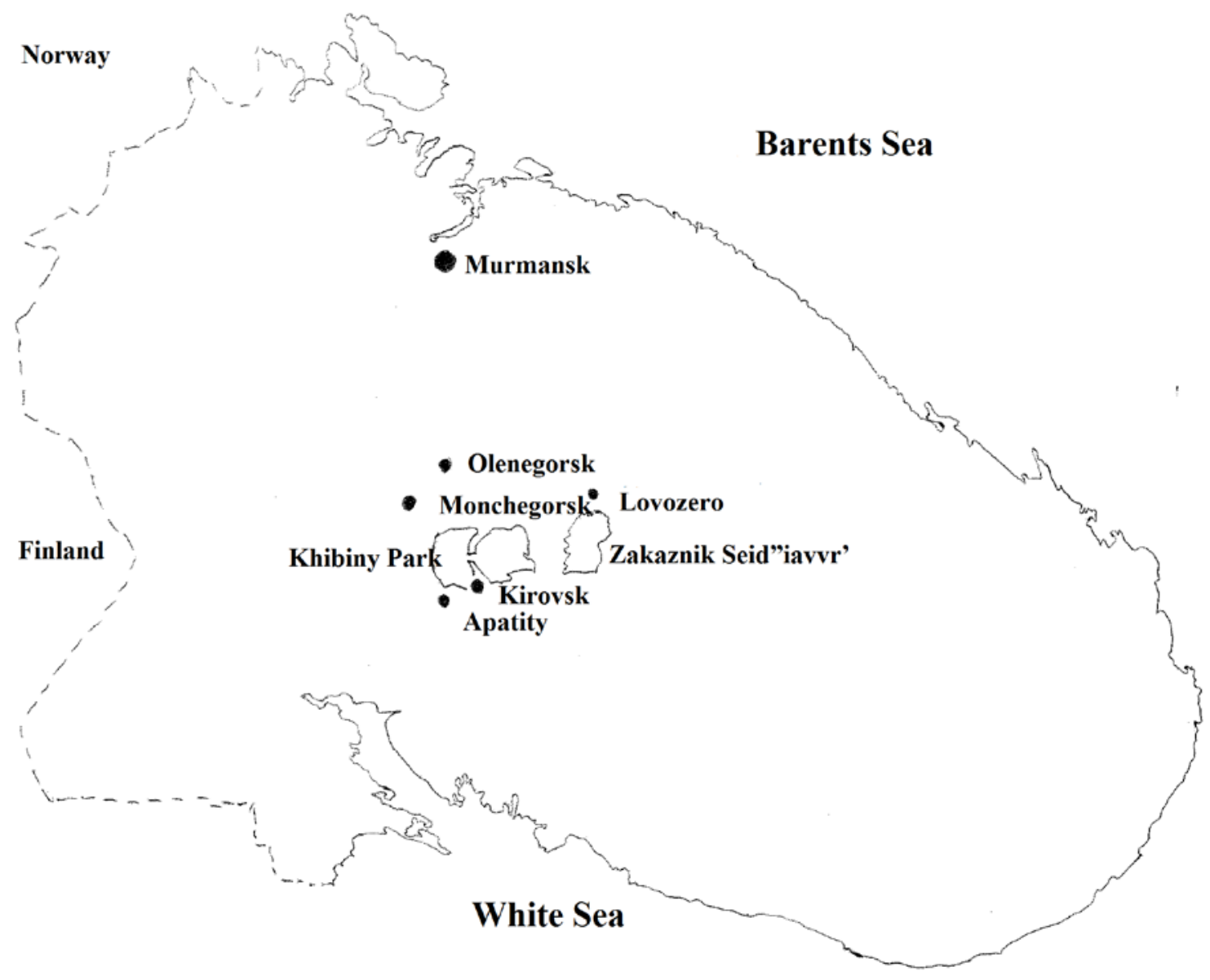

Figure 1: Kola Peninsula, Murmansk Region. (c) Vladislava Vladimirova 2017. 
The Sami indigenous revitalization movement initiated a number of bottom-up processes and demonstrated civil society in operation. While the state (centrally) and regional administrations (locally) are attempting to control the movement today, this was not always the case. In the early 2000s it was through the lobbying of an indigenous Sami organization that one of the Soviet nature reserves, Zakaznik Seid"iavvr', was re-established (Vladimirova 2016). The controversial relations between Seid"iavvr' and the Khibiny Park initiators will be mentioned later in the article.

\section{Nature conservation in Russia}

In order to grasp the dynamic of the process and the logic of events related to the struggle for establishment of the Khibiny National Park, a short introduction on Russian history and ideas of nature protection is needed. In Article 2 the Federal Law on "Protected Natural Areas" N33-FZ issued on March 14, 1995 stipulates area categories, the status of land and who has control of it, as well as levels of protection. Three categories - zapovednik, national park, and nature park - have relatively higher level of protection and are governed directly by the state, But most protected areas such as zakaznik and natural monuments are under the authority of regional administrations (Federal Law 'On Protected Natural Areas' Federal Law N33FZ 1995).

Zapovednik is the oldest form that continues to provide the highest level of restriction on human activities, including recreation. Its name comes from the verb zapovedat, to order (Reimers and Shtil'mark 1978: 12). Zapovedenie is a whole academic branch of study and the practice of protecting nature. In contrast to the dominant tourist orientation of early conservation practices in other parts of the world (Löfgren 1989; Mels 1999; Reinius 2009; Sörlin 1991) the Russian zapovedniki were seen as samples of pristine nature and habitats for species unaffected by humans. Such territories needed to be off-limits for agriculture and other economic activities, in order to preserve biodiversity and to study the development of biological systems through the organization of long term scientific observation (Reimers and Shtil'mark 1978). Simultaneously, in a slightly contradictory fashion, they were also seen a shelter where depleted species could recover and increase under the care of qualified specialists.

Zapovedniki were first founded by natural scientists and enthusiasts, and later in the Soviet period by scientific institutions. Some of them constituted scientific organizations themselves, and issued their own periodicals, such as the Laplandskii Zapovednik mentioned below. The first Law on Protected Natural Territories as well as mapping all existing zapovedniki was initiated in 1912 (Reimers and Shtil'mark 1978: 16). All these developments, despite their specific manifestations, should be seen in the context of a synchronous fast-growing worldwide interest in nature conservation. The pioneers of Russian conservation formed three somewhat consistent trends: preservation of biodiversity for its economic utility, for its scientific value, and for its "ethical - aesthetic" value. The latter proposed that protection should be motivated by nature's intrinsic right to exist without damaging interference (Reimers and Shtil'mark 1978: 9). In many cases, including in some of the earliest Soviet legal documents, intrinsic and aesthetic values were not clearly distinguished (Boreiko 1997). Later on, however, the scientific and utilitarian rationale outweighed ethical considerations, and aesthetics became politically controversial because Soviet ideologues condemned it as bourgeois (Reimers and Shtil'mark 1978).

In the Kola Peninsula the first zapovednik (Laplandskii) was organized in 1930 in order to preserve the quickly disappearing population of wild reindeer. The Executive Committee of Leningradskii Region took the decision to conserve $1,600 \mathrm{~km}^{2}$ of land and to employ three scholars and two guards. In the $1970 \mathrm{~s}$, the territory was increased considerably in order to follow wild reindeer migrations, and in the mid-1980s with its conversion to a Biosphere Reserve and inclusion on the UNESCO list. Laplandskii Zapovednik reflects the main principles of Soviet zapovedenie: it is a territory closed for most human activities, including visits, with the purpose of conservation of nature and scientific exploration (the "fortress" approach to conservation). The social history of the territory as an indigenous Sami habitat was entirely erased 
(Vladimirova 2016). Only recently has the construction of infrastructure for visitors to the Zapovednik been started, in connection with politicians' emphasis on eco- and ethnographic tourism as part of developing the Murmansk regional economy, as well as for generating resources to maintain and manage the area (Wells and Williams 1998: 203). This ideological shift in conservation has been notable in Russia since 2010, following a Governmental Decree that encourages the development of tourism in protected areas which are now expected to attract investors and cooperate with economic actors. Such neoliberal rationality, as scholars point out, valorizes reserves more in their role of generating revenue rather than for protecting nature (Müller 2014: 138-139). In the presentation of the future economy of Murmansk Region, tourism has been given a prominent role as a strategic area of development. At the same time the financial, infrastructural, and administrative obstacles for tourism development surpass any symbolic support that the authorities might grant (Vladimirova 2011). As my field research indicates, such values remain mostly in the sphere of ideology so far, while local people show mixed feelings about tourism. On the one hand, travel in nature is a common leisure activity. Zakaznik Seid"iavvr' and Khibiny Mountains are the most popular local destinations. Many interviews with local residents reveal a strong sense that tourism damages nature, especially in a situation of loose state controls and increased poaching. Such attitudes are more often directed against tourists coming from outside this region. In places under less strict regimes than Zakazniki, such as Seid"iavvr', limited fishing and gathering are allowed. Local residents, who benefit from such activities, consider tourists as competitors that deplete their resources (Konstantinov 2005; Vladimirova 2011). These contradictions indicate that local concepts of nature conservation can be closely entangled with diverse economic considerations, which the debate over the Khibiny project indicates.

\section{Khibiny Mountain National Park Project}

The Khibiny Mountains are in the central part of the Kola Peninsula, extending over 1,300 $\mathrm{km}^{2}$ and located between two lakes (Figure 2). They range in elevation with the highest peak being 1,201 meters. The mountains take the shape of a horseshoe topped by a high plateau, drained by a series of deep canyons. The overall terrain is alpine tundra. The Khibiny are extremely rich in minerals, mainly apatite and nepheline ores. The towns of Apatity and Kirovsk are situated near the mountain (Fersman 1960).

The idea of creating a protected territory in the Khibiny Mountains ${ }^{3}$ has been discussed since the 1980s, in connection with the establishment of the nearby zakaznik Seid"iavvr'. The local authorities showed a positive attitude in the early 1990s, but no further action followed. In 1997 The Institute for Industrial Ecology in the North together with the Polar Botanical Garden-Institute prepared a project for the creation of a National Park, and submitted it to the Committee of Ecology and Environment Protection, the Federal Forestry Agency, and the town administrations of Apatity and Kirovsk. In the same year, representatives of thirty-five organizations (led by the Kola Wildlife Protection Centre), including local, national and foreign NGOs, had a meeting at Seidozero Lake, and appointed a steering group.

The Institute for Industrial Ecology in the North, fulfilling an order from the Committee on Ecology and Environment Protection of Murmansk Region, prepared an ecological and economic assessment. In 2000, the Committee approved the project and recommended that the Government of Murmansk Region prepare an application to the Federal authorities. The assessment states that the most efficient way to conserve biodiversity is by creating protected territories. This follows Russia's endorsement in $1996^{4}$ of the International Union for Conservation of Nature's Strategy for Nature Protection, the main principles of which are the sustenance of ecological processes and systems, the preservation of genetic diversity, and the sustainable use of species and ecosystems. It may sound like a paradox, the authors, continue, but because of

\footnotetext{
${ }^{3}$ Information about the project has been taken from the webpage http://hibiny.info/documents, and the Facebook group Movement for Defence of Hibiny, when no other sources are specified in the text.

${ }^{4}$ The Russian government issued a Decree 'About Measures for fulfillment of the International Biodiversity Convention', and in 1996 the President ratified the frame for Russia's transition to sustainable development (Russian Academy of Science 2000).
} 
the dominant industrial economy in the region, with the densest population in the few highly industrialized urban areas, larger territories remain almost unaffected by humans. Despite western descriptions of extreme Soviet degradation of nature (Hønneland 2003; Richter 1997), severely damaged land in the region constitutes only $2.7 \%$ of its territory. At the same time, 243 protected areas exist in the European North of Russia, which occupy 5.2 \% of its territory (Russian Academy of Science 2000). To reform their inefficient management and security, however, in the face of increased private economic interest, corruption and unregulated tourism, requires urgent measures from the state and the international community (Ostergren and Jacques 2002).

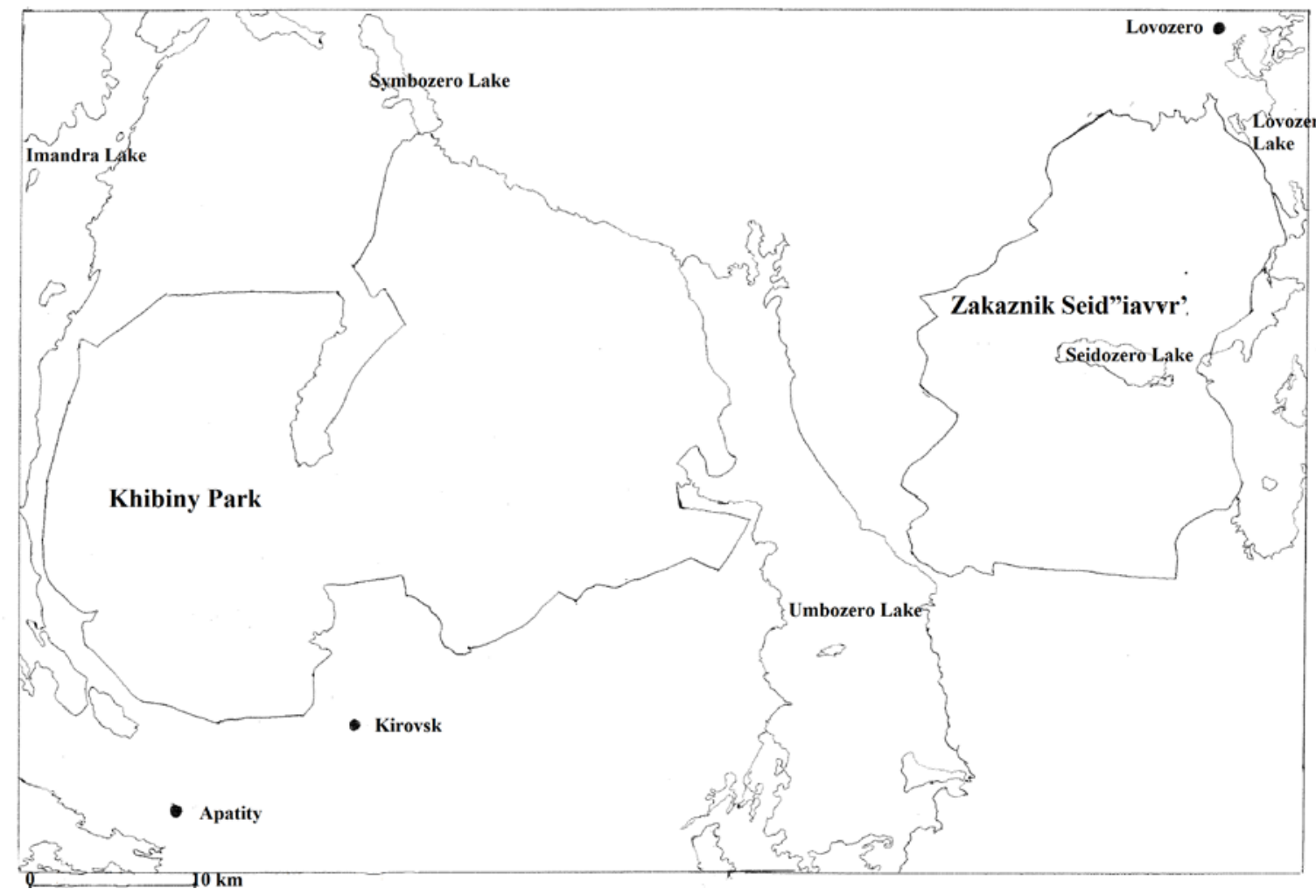

Figure 2: Khibiny Park and Zakaznik Seid”iavvr'. (c) Vladislava Vladimirova 2017.

The report also says that according to experts, Murmansk region needs more protected areas in order to preserve its biodiversity, with a special focus on areas that are the natural habitat for greater numbers of species. The vegetation of the Khibiny includes $40 \%$ of the species of vascular plants, $70 \%$ of bryophytes and $40 \%$ of lichens that are found in Murmansk region. Some of these species are known to live only in this location. The report emphasizes the potential of the park for recreational and tourism activities, and its role for the indigenous Sami. The economic efficiency of the park is difficult to define with any precision, the scholars explain, because of a number of factors, among which was the difficult economic situation of the region in the early 2000s (Russian Academy of Science 2000).

Despite the authorities' positive response and the assessment work, an application to create the park was not submitted. Possible explanations were the constant administrative reforms resulting from staff changes, the dismantling of the Soviet protected territories management system, and perhaps the interests of 
extractive companies. After no state organization managed to push it further, NGOs took over the project. As an alternative, they decided to change the organizational form to a nature park, for which the regional administration has the authority to take a decision. For this purpose, a new set of documents were prepared, and the borders of the future park were marked in the forest register. The project even received support from the then Governor of the region, but a change of leadership in 2009 slowed the process again.

One of the main problems that local bureaucrats point to is the lack of sufficient resources. Taking this into consideration, the project leaders agreed to postpone the creation of the park, but they wanted its future territory be "reserved" immediately, as the only way to limit allotment of land to industrial enterprises. Meanwhile, the national park project received support at the federal level when the Ministry of Natural Resources and Environment included it in its territorial planning scheme. When the Ministry realized that the work on the scheme was going to take too long, in order to speed up nature conservation, they issued an Ordinance called Concept for development of the system of protected areas of federal significance until 2020. This document, which was signed by V. Putin in December 2011, is, according to analysts, of a quality previously unseen in Russia: it states the objectives of nature conservation in each region and outlines a clear timeframe for their implementation. According to it, Khibiny Park was planned for 2015. Despite this allegedly positive development, environmentalists point out that bureaucrats have not been willing to fulfill the federal decision. Further, some of the agreements and documents necessary for the creation of the park will soon expire and issuing new ones is not guaranteed.

In the meantime, industrial developments that were begun in the Soviet period and continue into the present, heavily affect some zones of the planned park. Apatit and nepheline ores are a component for mineral fertilizers and aluminum production. Today, the biggest player is the Russian group Phosagro ${ }^{5}$, one of the world's leading phosphate-based fertilizer producer (Phosagro nd). Phosagro's biggest enterprise in the region is Apatit, which operates four mines with a total annual production capacity of about 27 million tons of ore. In the late 1990s the major stake in Apatit was controlled by Menatep, the bank associated with now exiled Mikhail Khodorkovsky and his Yukos Corporation. The apatite industry remains highly profitable in Murmansk which is the key region in Russia for its extraction. The production of the refined phosphate increased from 4.2 million tons in 2000 to 10.7 million in 2013 (Staalesen 2014).

Apatit mining and processing facilities are a serious source of pollution in the Khibiny area. They emit toxic aerosol elements in the atmosphere, especially in the vicinity of its tailings near the Lake Imandra. In addition, the bottom layers in tailings (some of which are more than 50 years old, and are now practically full) pollute groundwater and the rivers and lakes in the vicinity (Conservation nd). Nevertheless, the enterprise claims to have some of the best waste control facilities in the region, and as one of the biggest employers in the towns of Apatity and Kirovsk in a time of economic crisis, it easily finds support against environmentalists' criticisms.

In the last year, the position of Phosagro has been challenged by the competitor Acron and its subsidiary Northwest Russian Phosphorous Company, which was created in 2005 to develop apatitenepheline ore fields in the Khibiny mountains (Acron 2005). In 2012 the company launched Olenii Ruchei one of the biggest industrial projects of the last few decades. The phosphorous mine is located at the eastern border of the planned park (Staalesen 2012). The project includes both open pit and underground mining. Environmentalists saw the development as conflicting with the conservation plans made with the local and federal authorities. Work has begun, with a total of 89 structures erected on the site, 13,000 tons of metal equipment, with $41 \mathrm{~km}$ of pipelines and over $40 \mathrm{~km}$ of roads. The Northwest Phosphorous Company has already invested US\$430 million in the project, which will give an annual one million ton ore production (Staalesen 2012).

\footnotetext{
${ }^{5}$ PhosAgro's primary assets include Apatit, PhosAgro-Cherepovets (established as a result of the merger of Ammophos and Cherepovetsky Azot), Agro-Cherepovets, Balakovo branch of OJSC Apatit, Metachem, PhosAgro-Trans, PhosAgroRegion and NIUIF.
} 
Acron has also procured from the regional authorities a license to develop the Partomchorr field, located in the northern part of the Khibiny. Environmentalists question the economic efficiency of this project, because the ore, according to expert reports, contains 2-3 times less phosphorus. The economic rationality of the enterprise is thus under question. Well-established phosphorus producers such as Phosagro have sometimes failed to make an adequate profit, even though they have already paid off their capital investment. In 2010, Acron started cutting trees, building structures, and drilling at the location before the local authorities had even issued all necessary permissions (Baranovskii, Gar'kusha, and Kobiakov 2011). What raised public indignation was the statement of the Chair of the Company's Council of Directors that they did not consider illegal start of work a big violation. The Chair also expressed his positive attitude toward the Khibiny Park, but contended: "there is still no park, and it is not very likely that it will come into being, so it is not an issue" (Kobiakov and Ryzhov 2010).

What further escalated the conflict was the planned building of a road which connects Partomchorr with Olenii Ruchei across the Khibiny. The leaders of the company raised the argument that the development of tourism there carries serious risks, because of underground nuclear testing that took place in the 1970s and the 1980s. To this, environmentalists have answered that the company expresses no worry about the health of the people they employ to work underground in the mine. Environmentalists, ecologists, and tourist companies also stress the enormous destruction that the planned mine and road would cause to the fragile subarctic environment. Some of the most popular tourist routes will be interrupted. One further ethical criticism is that most of the company's production goes for export, while its leaders claim that they are helping Russian agriculture stand on its feet and thus they fulfill state objectives. Environmentalists observe that instead the company is really contributing to agricultural development somewhere else, through its fertilizers, while bringing considerable profit for Moscow entrepreneurs. The highest costs, however, shall be paid by local people, who will suffer environmental degradation, pollution, and decrease of income from local tourism development, for which the Khibiny name has become a brand (Kobiakov and Ryzhov 2010). To the company's strongest claim - that of creating jobs for local people - environmentalists cite the recent restructuring in Phosagro, after which hundreds of people lost their jobs. The Park protagonists underline the short-term versus long-term perspectives, in terms of economic development, nature impact, and social effects. The political and economic investment in the park will bring long-term positive effects in all these spheres, while mining will provide limited economic profit at the price of permanent destruction of the economic and natural basis of local communities. Thus the regional authorities, who allegedly support the park, but in reality promote big companies' interests disregarding local communities, have been condemned (Baranovskii, Gar'kusha, and Kobiakov 2011).

During the last few years, the struggle continues with varying success, but the company keeps changing its plans and increasing its demands, even though WWF has used its important influence in Russia to promote further negotiations (WWF 2013). When I wrote the first draft of this article, in late 2014, even though the Khibiny Park initiative group sounded optimistic, they admitted that once again instead of being submitted quickly to the federal authorities, documents were lying "on the desks" of the regional clerks, or as a local person described the situation "the normal bureaucratic procedure, admittedly somewhat prolonged" (Petrov 2014). Such delay can partially be due to banal reasons such as reorganization of the state agency responsible for subsoil, called in Russian Rosnedra, which meant no one knew at what level of their administration (federal or regional) the national park project should be approved.

As one more example of the level of bureaucratic hindrances, since 2014, the project needed the approval of all existing enterprises in Murmansk Region that might potentially have future economic interests within the borders of the park, which in this case are four. Their agreement, common logic dictates, can only be received if the park does not include any territory of possible interest to them. The expected result, as of the autumn of 2016, is that after Rosnedra's requirement for an updated approval by all mining companies of the park area, the latter posed further demands for diminishing the boundaries, excluding all areas of potential future mining, as well as territories bordering their current pits. Meanwhile Rosnedra is trying to push a new legal project, according to which certain mining activities can even take place in protected territories, 
segments of which should also be closed for tourists. Further, they would like to make sure that politicians and bureaucrats are delegated the right to change the size, borders and status of protected areas. The leader of the project then raised the painful question: what is the rationale with such new protected territories, if they cannot stop industrial encroachment?

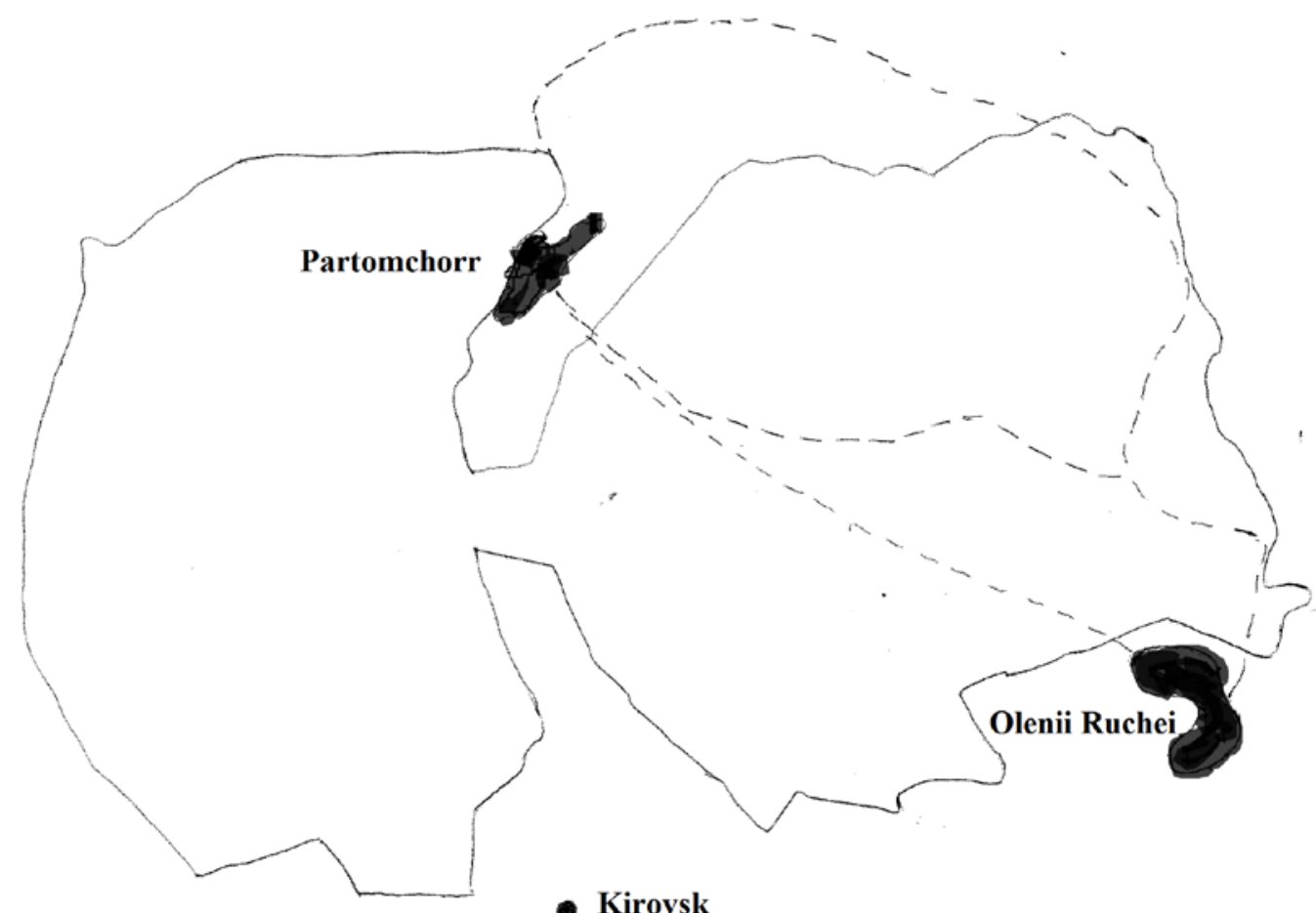

- Apatity

Figure 3: Part of the planned territory of Khibiny Park with the Partomchorr and Olenii Ruchei mines. Some proposed routes for transporting ore are marked with dotted lines. (C) Vladislava Vladimirova 2017.

\section{The micropolitics of the green economy}

As this brief account of the painful process of creating the park shows, in the existing political and economic situation, the application of law in Russia is not straightforward. A pattern appears of constant delay of official decisions that would grant legal status to the park, despite the promises of the bureaucrats. Direct opposition to the park project seems plausible only for representatives of big business, which shows that they see few threats to their power in peripheral regions like Murmansk, and they do not attribute much weight to the independent local authorities. This is not a surprising conclusion, given the economic hardship that many regions have experienced during the last 25 years (apart from Russia's core regions). The same mood of supporting at all costs any businesses that promise to create new well-paid jobs is not entirely foreign to ordinary people too. However, what most people find difficult to accept and strongly disapprove 
of, is that in contrast to Soviet times, companies serve primarily private economic interests and do not fulfill peoples' expectations for social support to the local communities. People are further frustrated by the apparent paradox of private businesses whose power seems to surpass that of the state administration.

Another important pattern is the lack of correspondence between legal provision and bureaucrats' statements and promises, on the one hand, and their practices, on the other. To give an example, despite the persistent claim of the regional administration that the role of environmental and civil organizations is decisive when it comes to nature and ecology, such organizations report that they encounter sometimes insurmountable difficulties. Viktor Petrov, one of the main protagonists for the establishment of Khibiny Park, raises the issue that there is no official provision at present that regulates the rights of local residents to express their opinion and to make sure it reaches the authorities. This can only be done through personal contacts (Ivanushkin 2014), since the official provision of sending letters does not work. According to the chairwoman of the Russian Sami Parliament, in the last two years, the regional Agency for Control in the Sphere of Nature Use, did not take action or respond to any of the legal violations reported by local residents. Environmentalists confirm that the agency refuses to cooperate with them and to answer their letters, as the law stipulates they must (Ivanushkin 2014).

Some facts about the history of the project and the region as a whole cast additional light on the difficulties it encountered, such as opposition from local residents and from the indigenous community. Most activists behind the project come from the industrial towns of Apatity and Kirovsk that were created during the Soviet period near mines, and populated mainly with immigrant workers from other Soviet regions. Another group of supporters is made up of small tourist companies from the region's capital Murmansk.

The village of Lovozero, on the other hand, with an indigenous population of 800 people, is the symbol of the Sami community, with its long history as a Sami village since the $16^{\text {th }}$ century. Ideologically and historically, these locations provide different attitudes and objectives among their respective residents, so cooperation is not easy. The bone of contention in this case is the locally famous Zakaznik Seid"iavvr', which is planned to be incorporated with Khibiny Park. The zakaznik is named for the lake, Seidozero, which has become renowned locally and nationally as a Sami sacred lake and attracts many visitors. In the first half of the 2000s, indigenous organizations managed to obtain legal confirmation of Seid"iavvr' as a zakaznik by the Regional Government. The relatively higher political weight of indigenous civil organizations in Russia until the mid-2000s, permitted bottom up agencies to influence local level government. In addition, the sacred 'aura' of the place constitutes strong symbolic capital. The zakaznik has a small administration consisting of one leader and two guards, with an office in Lovozero. While indigenous Sami are not directly involved in the government of the zakaznik, for the first time in the history of conservation in the region, the preservation of traditional Sami natural environment and culture have been included as goals (Decree 2003). The zakaznik was also expected to provide economic opportunities for the Sami, mostly through the development of private reindeer herding and ethnic tourism.

Russian law allows indigenous people to rent land and engage in traditional economic activities if they organize a non-profit organization called obshchina. One of the first Sami obshchiny, registered in the early 2002, succeeded with help from abroad in renting grazing land in the territory of Seid"iavvr' and acquiring some reindeer. Unfortunately, the obshchina's reindeer herding enterprise proved unprofitable. As an indirect result of the location of the obshchina grazing land in the zakaznik, local people pointed out that it encouraged obshchina members to get more actively involved in its informal tourist economy than in proper herding (Vladimirova 2011). Less biased analysis shows a number of historical, cultural, and bureaucratic obstacles that prevent Sami people from successful involvement with their traditional livelihoods (Konstantinov 2015; Vladimirova 2006). After two and a half decades of political struggle, many indigenous people start questioning the political methods and the ideals of justice promoted by the global indigenous movement, which they eagerly embraced in the 1990s. A mood of resignation spreading among the indigenous community can be detected in the words of the head of Zakaznik Seid"iavvr' during an interview I recorded in September 2014: "Sami seem to accept the status quo. If anyone wants to fish in Seidozero, they 
are welcome, but only from the shore, no boats because they mess things up. Sami don't seem to be interested in anything else."

From the perspective of Lovozero administration and the chair of Zakaznik Seid"iavvr', the creation of Khibiny Park - which is supposed to include Seidozero - would grant the land to the federal authorities for central management .This does not necessarily mean more secure protection of the area. Rather, they see a risk that Moscow bureaucrats would not feel the same attachment to the lake as locals, which might increase the unpredictability of its future. This shows how little trust local people, including regional bureaucrats, have in the representatives of the state, and their ability to comply with law.

Khibiny Park is one of the first projects in the region that provides for simultaneous nature protection and recreation and sport activities. This shift in nature conservation objectives is perhaps troubling for the residents of Lovozero. The indigenous community's primary attachment to the lake is based on their belief in its sanctity, and also its value as historical and cultural heritage (Vladimirova 2016). At the earlier stages of the park project many people in Lovozero were in favor of preserving the independence of Zakaznik Seid"iavvr' and hence were against the creation of Khibiny Park. Sami politicians believed that a compromise with the regional government regarding Sami management and land use of Seidozero was possible. During my field research in September 2014, however, some Sami politicians, represented by the chair of the Russian Sami Parliament raised a different argument. As a protected area, Seid"iavvr' did not fulfill the promised goal to become a basis for revival of Sami culture. The way it is governed now to attract even more tourists tends to alienate local people. Sami do not like the visits of big groups of outsiders to the lake. The chair of the Sami Parliament agrees that in creating the park, the land of the zakaznik, and sacred Sami territory, should become federal, i.e. be put under the control of Moscow. Nevertheless, she feels that the status quo is not beneficial to the Sami either, some of whom, facing so many hindrances, have begun to give up and accept the idea that perhaps their lives would be easier if they could just accept destruction of their ancestral land by mining - which might result in more stable employment.

The leaders of Khibiny Park project have also recently promised to the Sami to include one of their representatives in the park management, and hopefully provide some employment, since the park is supposed to hire 100-150 people. In an interview from September 2014, the Sami Parliament Chair shared her hope that the state, by taking over the Khibiny, including Seid"iavvr', would become a better guarantee for the protection of its natural and cultural features, at the core of indigenous culture. At least, this is the broader claim of Federal indigenous legislation, for example the Law on guarantees of the rights of the indigenous numerically-small peoples (Federal 1999). In the name of this bigger project, some Sami politicians seem to be ready for cooperation with environmentalists. At the same time, as other Sami remark in the 'Movement for Defense of the Khibiny' Facebook group, in their public campaign environmentalists do not emphasize the cultural value of the area that has been ancestral to Sami people for many centuries. Pessimists can interpret this as lack of genuine intention to cooperate with indigenous people and to take in consideration their interests. Others point out that in contrast to the successful public lobbying for Seid"iavvr', the Khibiny Park project has not involved Sami activists. This has hindered support from Nordic Sami and international lobbying in general, which could be an effective political mechanism to influence the final result of conservation processes like this one.

Thus Sami activists realize that they have important assets to offer in the future negotiations around Khibiny. The project would gain important political allies nationally and internationally. The weight of such an alliance is unquestionably a source of symbolic capital. Russian legislation on all levels, including the Arctic Strategy discussed above, makes a point of considering indigenous people and their interests. Even local authorities, who do not consistently follow the legal provisions, still make an effort to keep up to the image of observing the rights of indigenous populations. The success of Zakaznik Seid"iavvr' is a precedent that reinforces the value of indigenous support. Even Sami symbolic capital, however, can hardly counterbalance the power of big business. It can only adapt to it and try to profit from this enforced coexistence, as experiences from other parts of Russia show (Novikova 2014; Stammler 2011). 
Further difficulties that can ensue from such an alliance are related to conflicts within the indigenous community itself and its social and political segmentation. Divisions are often exacerbated by regional officials who are sometimes unable or unwilling to cooperate to solve indigenous problems, and apply a strategy of "divide and control," in order to weaken political opposition and consequently discredit the Sami community (Vladimirova 2014). In such an insecure legal and economic situation indigenous organizations and activists are disunited, and always on the search for allies in the conflicts among them. In this way, cooperation with one Sami organization, like the Sami Parliament, does not insure the support of the whole community and in some cases even generate animosity. In short, cooperation with Sami politicians cannot unambiguously promise a successful finale to the project, because it can result in unpredictable effects.

\section{Discussion: Russia is too green for the green economy ${ }^{6}$}

In Arctic Strategy 2020 President Putin signaled environmental security and ecological awareness as pillars of Russia's Arctic policy. Speaking at the International Arctic Forum in Moscow in 2010, when still Prime Minister, he said that the country will implement the highest environmental standards, and that not a single industrial project would proceed unless the strictest possible environmental requirements are met. When targeting the nation, however, he relies on other symbols, such as economic wellbeing, jobs, public care and social security, and finally patriotism. As analysts correctly observe, some of Russia's more radical political statements in the international arena have actually been directed mostly at its own citizens, gaining credibility for the leadership (Wilson Rowe and Blakkisrud 2014).

Russia's Arctic Strategy priorities are not disconnected from green economy objectives, and can be translated into the latter. At the same time, the selection of domestic green economy discourse is adjusted to relate to traditional symbols, such as scientific innovation, economic and cultural modernization, and generally progress, i.e. to values that are all well rooted in Soviet ideology, and hence appeal to a large part of the nation. The widely discussed Russian potential for greening of the energy sector through optimized use and development of alternative nature-friendly technologies, however, becomes represented in the domestic strategy in terms of securing enough energy through discovery of more mineral resources and big state investments following the principles of public-private partnership. In this context, ironically, protection of the environment is mostly mentioned in reference to increased industrial exploitation of the Arctic and to environmental security.

Economic growth is inherent in the green economy paradigm, and as critical scholars point out, this reproduces existing neoliberal policies and corporate business interests, attempting to "fix" their legitimacy (Brown et al. 2014: 248, and Arsel and Büscher 2012; Ferguson 2015; Finley-Brook 2007; Kenis and Lievens 2015: 231; Wanner 2015). In this context, Russian invocations of the green economy discourse both abroad and at home are not radically different. What is perhaps more distinctively a Russian tendency is the contrast between the official political statements of intention for greening and economic and administrative practices that block the same process. As Russian scholars and activists point out, state authorities take the side of, and depend upon, the extractive industry sector.

In the evolving "ecology of the pipe", environmental concerns are of subordinate importance, as are other stakeholders that might challenge mining's superiority. Powerful economic actors can openly and aggressively oppose public claims which they conceive of as encroachment. At the same time, regional authorities show a preference for bureaucratic technologies of power in order to avoid challenging extractive companies' interest in confrontations. In this political environment, it seems that in Russia, as in other parts of the world, the green economy discourse acts against the interest of communities, as represented by civil society organizations and ordinary citizens. By maintaining the legitimacy of extractive business, growing under the paradigm of mastering the Arctic for continuous economic development as the only means to poverty alleviation and improved economic conditions, the green economy indeed facilitates the strong

\footnotetext{
${ }^{6}$ Salnik 2012.
} 
political and economic power of the oligarchs and other elites. The Khibiny Park is a revealing example of the bureaucratic mechanisms that are used to produce increasing inequality of access to natural resources.

The most analytically intriguing aspect of this study comes from the stark contrast between the official approval of the project shown by the authorities over the years, and their strong resistance to putting anything concrete into effect. The attitude of the present Governor epitomizes this "double standard" policy. From 2009, in the popular WWF journal Pandatimes, the Governor, then a member of the Regional Department of Economic Development, was quoted as assessing the landscape, forest, and recreational capacities of the Khibiny in glowing terms:

The national park will preserve nature and its value for sustainable development. No profit from industrial development is worth the damage that they would cause to the Khibiny. (Kobiakov and Ryzhov 2010; Ryzhov 2009).

As environmental activists notice, the Governor has decorated her Facebook profile with pictures from the Khibiny Mountains. At the same time, even though she is one of the politicians pushing for the development of tourism, she has not yet attempted to intercede with mining companies or to show political support for the Park.

This ambiguous bureaucratic behavior can perhaps become clearer in sight of the strong support the project has received from civil society organizations and the public. The strategic use of the green economy rhetoric from below while having little power in attracting real support from businesses and bureaucrats, still managed to avoid open rejection. It seems then that the green economy is an ideology with which Russia wants to show engagement. Although as a plan of action, green economic principles have not reached the wider Russian public, their symbolic weight in the discursive sphere cannot be ignored. The presentation of the Khibiny Park project in relation to the green economy also attracted the support of youth ecological organizations from neighboring Nordic countries, who tried to popularize the project abroad and also took part in public protest in Murmansk in 2012. Their attempts have not produced results, except attention from Russian immigration authorities who demanded that foreign participants pay a fine because their tourist visas did not allow participation in public protests.

Russia's care for its international image is obvious in the statement of the special Representative of the Russian President at the conference International cooperation in the Arctic: new calls and vectors of development that took place in Moscow in September 2016. He said that by 2020 two new national parks will be created in the Russian Subarctic, one of which is Khibiny Mountains. In his words, $80 \%$ of all Arctic biological diversity exists within the Russian part, thus imposing a high responsibility on the nation to preserve it (Mamontov 2016).

Since 2010, a certain centralized political effort has begun to promote neoliberal nature conservation, indicated in legal changes. Such efforts are supported by the idea that investment in tourism infrastructure and establishment of a "unifying brand of Russian protected areas" can generate revenues to sustain nature protection as well as local communities (Müller 2014: 138). This policy has been directed at zapovedniki, the reserves with highest level of restriction. This top-down attempt at imposition of economic rationality has been condemned as compromising the main objective of nature conservation through risks of overexploitation by private stakeholders in the context of weak state regulation and flourishing corruption. Miller admits that the Russian economic and political model contributes to a "piecemeal approach" to these centralized goals in economic development. Regional managers and administrators choose whether to undertake development initiatives or not, in tourism and other economic activities in such protected territories (op.cit.). Khibiny Park is designed as a state organization, and as such its establishment is directly dependent on state investment and state government. Nevertheless, the ideology based in global neoliberal nature conservation and its Russian interpretation have shaped this project, contributing concepts, models, and rationales. Hence, some of the critical concerns raised about the latter are relevant in Russia as well. In 
the first place, the specialty of the Khibiny as a protected territory for both biodiversity conservation and recreation does not fit historical approaches to zapovedenie. National parks have always been the minority among Russian reserves. In this context, to create a protected area that serves the tourist industry is a new phenomenon that undermines older models of conservation. The tourism aspect of Khibiny Park, which its organizers stressed in order to increase the attraction of the project to the authorities, has been questioned by local people. Skeptics pose legitimate questions about who is going to benefit from this public project, and mistrust the environmentalists' motives. The promise of providing jobs and allowing Sami to participate in managing the future park to gain the support of the indigenous community is another previously unknown practice. Thus, newly imported practices and vocabulary, in part stimulated by bureaucratic requirements, introduce tensions among project proponents and members of local communities. The vocabulary that the local imaginary attributes to Western capitalist realities, and views it as somewhat incompatible with local ideologies and values that still reflect Soviet collectivist ideals and morality (Vladimirova 2006).

Further, arguments related to creating the park propose that the initial investment from the regional budget will result in future financial gains. The organizers had to admit that at this early stage it is difficult to measure the economic profit. But the need to consider market profitability of the protected area indicates the new trend in conservation discourse (Müller 2014). While it is not private investment that is envisaged here, it becomes clear that generating returns is a goal. The imposition of the language of economics as part of the debate about the park, and its internalization by environmentalists serve as warnings, by pointing to the increasing domestication of concepts, ideas, and rationalities that belong to neoliberal nature conservation. The "conceptual neoliberalization" of conservation, its negative effects, some of which I mention above, have been subject to scholarly critique in many parts of the world. The performative effects of such vocabulary, its power to produce rationalities, places and subjectivities, its educational and disciplining effects have been pointed out. An array of power techniques make the incommensurability of capitalist production with nature protection less visible, and a weaker shared human ethical engagement with it (Büscher et al. 2012; Dempsey and Suarez 2016; Sullivan 2009, 2012, 2013a). Future research on conservation in Russia can perhaps reveal more about how a neoliberal vocabulary educates people in a neoliberal capitalist ideology. Such ideology might be instrumental in confronting still-strong collectivist ethics and ideals in Russia, and producing broad rationalities that are more tolerant and accepting of domination by private business interests.

\section{Conclusion}

Russian analysts see strong state involvement as the main guarantee for the development of the green economy. In this sense they are not in full agreement with other scholars who see civil society as a mechanism that can promote global economic greening. Independent local, national, and cross-border nonprofit and non-governmental organizations, community groups, the free media and scholars are needed to

....cultivate a vibrant extra-market realm of life that gives relevant and effective expression to noncommercial concerns, principally focused on social justice and environmental sanity" that are capable of opposing hegemonic economic power. (Wapner 2011: 526)

Others seem to be more pessimistic about the ability of the conventional units of civil society to face the solidifying power of corporate capital, which the green economy paradigm mostly favors. Some scholars fear that the green economy discourse, and neoliberal nature conservation as part of it, provide ideological tools to discipline and govern society by cultivating a shared dominant capitalist ontology (Büscher et al. 2012; Sullivan 2009; Wanner 2015). The present study extends this analysis into Russia. Civil society is generally locally-based, i.e. it has political effects in a limited geographical area and symbolic and social capital are its main resources. As the unfinished struggle over the Khibiny suggests, these are not adequate tools to confront big extraction companies protected by the authorities. In the Russian context, even Wanner's otherwise persuasive suggestion, to develop "a consciousness of contradictions" through vigilance and "challenge of the popular common sense" (Wanner 2015: 36), does not seem effective. Future research can 
perhaps look into the "ecology of the pipe" as it is mastering or taking over (osvoenie) new cultural and psychological realms by demanding, teaching about, and advertizing capitalist ideals and rationality.

I will conclude the article with a speculation. I have not conducted research on a large enough scale to claim that the discourse of nature conservation and the green economy are part of a new passive revolution in Arctic Russia (Gramsci 1971: 366; Wanner 2015: 25). Instead, the research discussed in this article and my analysis point to ongoing work to establish and strengthen neoliberal and capitalist ideology and rationalities. Russia lacks a well-established civil society and a strong environmental movement that could pose a threat to the political and economic domination by elites, and challenge their ideological hegemony. Hence, the latter do not have an acute need to employ the green economy in the country in order to maintain their power. Thus, the green economy in Russia cannot be seen as part of Wanners' new passive revolution, even though the study shows that green economy rhetoric has some life and that environmental concerns do constitute a field of struggle against elites. In general, however, the analysis shows that if we follow Wanner and see the global green economy as a passive revolution, Russia, as a local journalist exclaims, "is too green for the green economy" (Salnik 2012).

\section{References}

Acron, G. Acron established CJSC North-West Phosphorus Company, 10 June 2005 [Available from http://www.acron.ru/en/presscenter/pressreleases/2818/].

Alexander, S.E. 2000. Resident attitudes towards conservation and black howler monkeys in Belize: the Community Baboon Sanctuary. Environmental Conservation 27 (04): 341-350.

Allen, C. and S. Clouth. 2012. A guidebook to the green economy. Issue 1: Green economy, green growth, and low-carbon development-history, definitions, and a guide to recent publications. Division for Sustainable Development, Department of Economic and Social Affairs. New York: United Nations.

Andreassen, N. 2016. Arctic energy development in Russia-how "sustainability" can fit? Energy Research and Social Science 16: 78-88.

Anufriev, V.N., E.I. Anufrieva, and L.A. Petrun'ko. 2014. Povysheniye konkurentosposobnosti regionov i predpriyatiy za schet zelenoy ekonomiki(na primere Sverdlovskoy oblasti) [Improving the competitiveness of regions and enterprises by force of green economy]. Vestnik UrFU. Seriya ekonomika i upravleniye 3:134-145.

Arsel, M. and B. Büscher. 2012. Nature ${ }^{\mathrm{TM}}$ Inc.: changes and continuities in neoliberal conservation and market-based environmental policy. Development and Change 43(1): 53-78.

Baranovskii, P., M. Gar'kusha, and S. Kobiakov. 2011. Proekt Razrabotki Partomchorr /Partomchorr Mining Porject/. [Available from http://hibiny.info/problems/partomchorr]. Accessed November 2016.

Belitskaya, A. nd. Public private partnership in the energy sector of Russia: legal aspect. [Available from http://hibiny.info/problems/partomchorr]. Accessed November 2016.

Boreiko, V.E. 1997. Vvedenie $v$ prirodookhrannuiu estetiku [Introduction to the esthetic of nature protection]. Kiev: KEKC.

Brockington, D. and R. Duffy. 2010. Capitalism and conservation: the production and reproduction of biodiversity conservation. Antipode 42: 469-484. Researchgate

Brockington, D. and J. Igoe. 2006. Eviction for conservation: a global overview. Conservation and Society 4(3): 424-470.

Brockington, D., and J. Igoe. 2007. Neoliberal conservation: a brief introduction. Conservation and Society 5(4): 432-449. 
Brown, E., J. Cloke, D. Gent, P.H. Johnson, and C. Hill. 2014. Green growth or ecological commodification: debating the green economy in the global South. Geografiska Annaler: Series B, Human Geography 96(3):245-259.

Büscher, B., W. Dressler and R. Fletcher (eds.). 2014. Nature Inc.: environmental conservation in the neoliberal age: University of Arizona Press.

Büscher, B., S. Sullivan, K. Neves, J. Igoe, and D. Brockington. 2012. Towards a synthesized critique of neoliberal biodiversity conservation. Capitalism Nature Socialism 23(2): 4-30.

Caprotti, F. 2012. The cultural economy of cleantech: environmental discourse and the emergence of a new technology sector. Transactions of the Institute of British Geographers 37(3): 370-385.

Caprotti, F. and I. Bailey. 2014. Making sense of the green economy. Geografiska Annaler: Series B, Human Geography 96(3): 195-200.

Carrier, J.G. and D.V. Macleod. 2005. Bursting the bubble: the socio-cultural context of ecotourism. Journal of the Royal Anthropological Institute 11(2): 315-334.

Castree, N. 2008. Neoliberalising nature: the logics of deregulation and reregulation. Environment and Planning A 40(1):131-152. Researchgate

Centre. 2011. The Russian Federation. an assessment of assessments. Moscow: The Russian Regional Environmental Centre.

Conservation. nd. Ocenka ekologicheskoi situacii Istochniki zagriaznenia prirodnykh sred otkhodami deiatel'nosti cheloveka/Ecological assessment: anthropogenic sources of nature pollution. Moscow: Biodiversity Conservation Center.

Danilenko, L. N. 2013. Ekologicheskaia politika v Rossii: "zelenaia " ekonomika protiv rentno-syr'evaia [Ecological policies in Russia: "green" economy against raw-material-intensive economy]. Nacional'nye interesy: prioritety i bezopasnost' 12(201): 38-47.

Death, C. 2014. The green economy in South Africa: global discourses and local politics. Politikon 41(1):122.

Decree. 2003. Decree from 31 March 2003 N 96 - PP/5 about Corrections to the Decision of the Executive Committee of Murmansk Regional Council of People's Deputees from 24 November 1982 N 538 'About the Organization of Complex State Zakaznik Seidozero'

Dempsey, J., and D.C. Suarez. 2016. Arrested development? The promises and paradoxes of "selling nature to save it". Annals of the American Association of Geographers 106(3): 653-671.

Dmitriev, A. 2013. Putin podpisal strategiou osvoenia Arktiki/Putin signed the Arctic Strategy.

Duffy, R. 2010. Nature crime: how we're getting conservation wrong. New Haven: Yale University Press.

Duffy, R. 2013. The international political economy of tourism and the neoliberalisation of nature: challenges posed by selling close interactions with animals. Review of International Political Economy 20(3): 605-626.

Duffy, R. 2015. Nature-based tourism and neoliberalism: concealing contradictions. Tourism Geographies 17(4):529-543.

Environment. 2011. Europe's environment: an assessment of assessments. Copenhagen: Denmark: European Environment Agency.

Facility. 2014. Russian Federation sets ambitious targets for environmental protection in the Arctic 2009. UNEP/Global Environment Facility. Available from http://www.thegef.org/gef/node/2204. Accessed November 2016.

Favorskaia, M. 2008. Potrebliaem Khibiny [Consuming the Khibiny]. Eko Style(1): 22-24.

Federal, Law. 1999. The Federal law 'On Guarantees of the Rights of the Indigenous Small-Numbered Peoples of the Russian Federation'. Moscow: Russian Federation. 
Federal Law N33-FZ 1995. Federal Law 'On Protected Natural Areas'. 33-FZ. Russian Federation and UNEP/GEF. 2009. Moscow: Strategic Action Programme for Protection of the Russian Arctic Environment.

Ferguson, P. 2015. The green economy agenda: business as usual or transformational discourse? Environmental Politics 24(1): 17-37.

Fersman, A. E. 1960. Puteshestvie za kamnem [Following the stone]. Moscow: Soviet Academy of Science.

Finley-Brook, M. 2007. Green neoliberal space: the Mesoamerican biological corridor. Journal of Latin American Geography 6(1):101-124.

Fletcher, R. 2010. Neoliberal environmentality: towards a poststructural political ecology of the conservation debate. Conservation and Society 8(3): 171-181.

Fletcher, R. 2012. Using the master's tools? Neoliberal conservation and the evasion of inequality. Development and Change 43(1): 295-317.

Forsyth, J. 1994. A history of the peoples of Siberia: Russia's North Asian colony 1581-1990: Cambridge University Press.

Goldman, M. 1998. Introduction: the political resurgence of the commons. In M. Goldman (ed.) Privatizing nature: political struggles for the global commons. New Brunswick: Rutgers University Press. Pp. 119.

Goldman, M. 2001. Constructing an environmental state: eco-governmentality and other transnational practices of a 'green'World Bank. Social Problems 48(4):499-523.

Gramsci, A. 1971. Selections from the Prison Notebooks of Antonio Gramsci. Ed. and Transl. by Quintin Hoare and Geoffrey Nowell Smith. Lawrence and Wishart.

Gushchina, E.G. and N.I. Badrak. 2013. Energeticheskaia effektivnost' Rossiskoi ekonomiki i "zelenye investicii [Energy efficiency of the Russian economy and "green investments"]. Nacional'nye interesy: prioritety i bezopasnost' 224(35): 44-50.

Henry, L.A. 2010. Red to green: environmental activism in post-Soviet Russia. Ithica: Cornell University Press.

Himley, M. 2008. Geographies of environmental governance: the nexus of nature and neoliberalism. Geography Compass 2(2):433-451.

Hønneland, G. 2003. Russia and the West: environmental co-operation and conflict. London: Routledge.

Ianickii, O. 2010. Izmeniaiushchiisia mir Rossii: resursy, seti, mesta [The changing world of Russia: resources, networks, places]. Mir Rossii(3): 12-16.

Igoe, J. 2010. The spectacle of nature in the global economy of appearances: anthropological engagements with the spectacular mediations of transnational conservation. Critique of Anthropology 30(4): 375397.

Ivanushkin, G. 2014. Ekologi Murmanskoi Oblasti zaiavili o trudnostiakh pri vzaimodeistvii s mestnymi vlastiami/Environmentalists in Murmansk Region complain of difficult cooperation with regional authorities. Social Information Agency 2014 [cited 26 Neovember 2014]. Available from https://tinyurl.com/hneuk96. Accessed November 2016.

Jänicke, M. and K. Jacob. 2009. A third industrial revolution? Solutions to the crisis of resource-intensive growth. Berlin: Forschungsstelle für Umweltpolitik FFU.

Kenis, A. and M. Lievens. 2015. Greening the economy or economizing the green project? When environmental concerns are turned into a means to save the market. Review of Radical Political Economics: 48(2): 217-234. Researchgate

Knox-Hayes, J. and J. Hayes. 2014. Technocratic norms, political culture and climate change governance. Geografiska Annaler: Series B, Human Geography 96(3): 261-276. 
Kobiakov, K. and M. Ryzhov. 2010. SZFK: turizm v Hibinakh smertel'no opasen!/SZFK: Tourism in the Hibiny is a deadly risk! [Available from http://hibiny.info/main/80-szfktourizm] Accessed November 2014.

Konstantinov, Y. 2005. Reindeer-herders: field-notes from the Kola Peninsula, 1994-95. Uppsala: Uppsala Universitet.

Konstantinov, Y. 2015. Conversations with power. Soviet and postSoviet developments in the reindeer husbandry part of the Kola Peninsula. Uppsala: Uppsala University.

Kravchenko, E. 2009. Rossia ne tratitsia na ekologiiu [Russia does not waste resources on ecology]. Vedomosti, 30 September.

Krüger, O. 2005. The role of ecotourism in conservation: panacea or Pandora's box? Biodiversity and Conservation 14(3):579-600.

Kuzhelev, E.D. 2014. Zelenaia ekonomika kak faktor ustoichivogo razvitiia ekologicheskoi bezopasnosti v sovremennom mire [Green economy as a factor of sustainable development of environmental safety in the modern world]. Nacional'naia bezopasnost' i strategicheskoe planirovanie 6(2):103-106.

Lagunina, I. 2008. Gazprom, poshchadi Khibiny! Murmanskie ekologi protiv Rossiiskogo giganta [Zazprom, Have mercy on Khibiny! Murmansk ecologists againt the Russian giant]. Eko Style (1):25-27.

Laplandskii, Z. 2015. Kratkaia istoria zapovednika [Short History of the Zapovednik] [cited 15 September 2015]. Available from http://www.laplandzap.ru/pages/2/. Accessed May 2016.

Lavrikova, Y. G. and E. V. Malysh. 2014. Zelenaya ekonomika v klasternom razvitii [Green Economy in Cluster Development]. Vestnik UrFU. Seriya ekonomika i upravleniye (3): 120-133.

Levine, A. 2002. Convergence or convenience? International conservation NGOs and development assistance in Tanzania. World Development 30(6): 1043-1055.

Likhachev, V. 2008. Prodolzhaem zhit' kak zhili /We continue living as usual. Eko Style 1(1):1.

Löfgren, O. 1989. Längtan till landet Annorlunda. In O. Löfgren, G. Andolf, T. Lunden, P. Bohm and L. Emmelin (eds.) Längtan till landet Annorlunda. Om turism i historia och nutid. Gidlunds Bokforlag.

Mamontov, S. 2016. Ivanov: Do 2020 goda v RF budet sozdano dva nacional'nykh parka v priarkticheskoi zone [Two National Parks will be created in the Russian Subarctic by 2020]. [Available from http://ru.arctic.ru/resources/20161013/464792.html]. Accessed November 2016.

Mau, V.A. and I.I. Kuz'minova. 2013. Strategia - 2020: Noavaia model' rosta - novaia social'naia politika/Strategy 2020: New growth model - new social policy. Moscow: Russian Government, Russian Agricultural Academy, Moscow School of Economics.

McAfee, K. 2012. The contradictory logic of global ecosystem services markets. Development and Change 43(1): 105-131.

Mels, T. 1999. Wild landscapes: the cultural nature of Swedish National Parks. Lund: Lund University Press.

Müller, M. 2014. From sacred cow to cash cow: the shifting political ecologies of protected areas in Russia. Zeitschrift für Wirtschaftsgeographie 58(2-3):127-143.

Niezen, R. 2010. Public justice and the anthropology of law: Cambridge University Press.

Novikova, N. 2014. Ohotniki i neftianiki. Issledovanie po iuridicheskoi antropologii [Hunters and oil workers. study of legal anthropology]. Moscow: Nauka.

Nuttall, N. 2013. Russia and UNEP sign agreement to strengthen partnership. UNEP News Centre.

Onishchenko, M. V. 2014. Rol' gosudarstva v razvitii "zelenoi ekonomiki" [State's Role in the Development of the "Green Economy". Nauchny zhurnal Kubanskogo Gosudarstvennogo Agrarnogo Universiteta (102(08). 
Ostergren, D. and P. Jacques. 2002. A political economy of Russian nature conservation policy: why scientists have taken a back seat. Global Environmental Politics 2(4):102-124.

Øverland, I. 2010. Russia's Arctic energy policy. International Journal 65(4):865-878.

Øverland, I., and M. Berg-Nordlie. 2012. Bridging divides: ethno-political leadership among the Russian Sámi. New York: Berghahn Books.

Pakhomova, N.V., K.K. Rikhter, and G.B. Malyshkov. 2013. Strategiya ustoychivogo razvitiya i perekhod k zelenoy ekonomike: obnovleniye prioritetov i mekhanizmov [The strategy for sustainable development and transition to green economy: update of priorities and mechanisms]. Vestnik of Saint Petersburg University 5(4): 35-54.

Panusittikorn, P. and T. Prato. 2001. Conservation of protected areas in Thailand: the case of Khao Yai National Park. Protected Areas East Asia 18(2):67-76.

Petrov, V. 2014. Post in Hibiny Park Movement. Facebook.

Phosagro, nd. About the company [cited. Available from http://www.phosagro.com/about/]. Accessed November 2016.

Porfiriev, B. 2013. Green economy: realities, prospects, and limits to growth. Moscow: Moscow Carnegie Center.

REGNUM, I. 2010. Dmitrii Medvedev: piat sostavliaiushchikh 'umnoi politiki' Rossii /Dmitrii Medvedev: The five components of intelligent policy in Russia.

Reimers, N.F. and F.R. Shtil'mark. 1978. Osobo okhraniaemye prirodnye territorii [Protected nature territories]. Moscow: Mysl.

Reinius, S.W. 2009. Protected attractions: tourism and wilderness in the Swedish mountainous region. Department of Human Geography. Stockholm: Stockholm University Press.

Richter, B.S. 1997. Nature mastered by man: ideology and water in the Soviet Union. Environment and History 3(1): 69-96.

Rodionova, I. A. and S. A. Lipina. 2015. Zelenaia Ekonomika v Rossii: model' i prognozy razvitiia [Green Economy in Russia: model and forecast of development]. Fundamental Research: Economic Sciences (2):5462-6.

Russian Academy of Science. 2000. Ecological and economic assessment of the Hibiny National Park. Institute for Industrila Ecology in the North.

Ryzhov, M. 2009. Khibiny nuzhdaiutsia v okhrane [Khibiny Need Protection]. Pandatimes (June):10.

Salnik, V. 2012. Rossia ne dorasla do zelenykh tekhnologii /Russia is Too Green for the Green Economy In Pravda. [Available from http://www.pravda.ru/economics/rules/19-07-2012/1122239-green-0/]. Accessed November 2014.

Schmidt-Soltau, K. and D. Brockington. 2007. Protected areas and resettlement: what scope for voluntary relocation? World Development 35(12): 2182-2202.

Shear, B.W. 2014. Making the green economy: politics, desire, and economic possibility. Journal of Political Ecology 21: 193-209.

Shvarts, E. and A. Knizhnikov. 2012. Ekologicheskii imperativ, ekologicheskaia politika Rossii 2000-kh i konkurentnosposobnost' ekonomiki [The ecological imperative, ecological policy in Russia in the 2000s and the economy's ability to compete]. Obshchestvennye nauki i sovremennost' (4):33-35.

Slezkine, Y. 1994. Arctic mirrors: Russia and the small peoples of the North. Ithaca: Cornell University Press.

Ssorin-Chaikov, N.V. 2003. The social life of the state in Subarctic Siberia. Stanford, Calif.: Stanford University Press. 
Staalesen, A. 2012. Acron launches the Oleniy Ruchey. In Barents Observer. [Available from http://barentsobserver.com/en/business/acron-launches-oleniy-ruchey-30-07]. Accessed November 2014.

Staalesen, A. 2014. Growing appetite for Murmansk apatite. In Barents Observer. [Available from http://barentsobserver.com/en/business/2014/07/growing-appetite-murmansk-apatite-25-07]. Accessed 6 March 2017.

Stammler, F. 2011. Oil without conflict? The anthropology of industrialisation in Northern Russia. In A. Behrends, S.P. Reyna and G. Schlee (eds.) Crude domination: an anthropology of oil. New York, Oxford: Berghahn. Pp. 243-269.

Stepanov, S.A. 2012. RIO +20 i modernizacionny potencial Rossii: Obrazovatel'nye aspekty/RIO + 20 and modernization potential of Russia: educational aspect. Pedagogics 20(2): 25-34.

Stern, N. and J. Rydge. 2012. The new energy-industrial revolution and an international agreement on climate change. Economics of Energy and Environmental Policy 1(1):1-19.

Stokke, O.S., G. Hønneland, and P.J. Schei. 2006. Pollution and conservation. In O.S. Stokke and G. Hønneland (eds.) International cooperation and Arctic governance: regime effectiveness and Northern region building. London and New York: Routledge. Pp. 78-111.

Strategy, R.A. 2013. Startegia Razvitia Arkticheskoi zony Rossiiskoi Federacii/Strategy for development of the Arctic Zone of the the Russian Federation. Moscow: Governemnt of the Russian Federation.

Sukhdeva P. nd. Strategiia 'zelenaia ekonomika' [The strategy of the green economy] [Available from http://www.palata.zhkh.kz/?p=750]. Accessed November 2014.

Sullivan, S. 2006. The elephant in the room? Problematizing 'new' (neoliberal) biodiversity conservation. Forum for Development Studies 33(1): 105-135.

Sullivan, S. 2009. Green capitalism, and the cultural poverty of constructing nature as service-provider. Radical Anthropology 3: 18-27.

Sullivan, S. 2012. Financialisation, biodiversity conservation and equity: some currents and concerns. Environment and Development Series 16, Penang Malaysia: Third World Network.

Sullivan, S. 2013a. Banking nature? The spectacular financialisation of environmental conservation. Antipode 45(1): 198-217.

Sullivan, S. 2013b. The natural capital myth. The Public Political Ecology Lab, University of Arizona.

Sullivan, S. and M. Hannis. 2014. "Mathematics maybe, but not money": on the nature of numbers, and the numbers of nature. Talk, at Ecological accounts: making non-human worlds (in)visible during moments of socio-ecological transformation. University of St. Andrews.

Sörlin, S. 1991. Humanekologi: vägar till överlevnad. Umeå: Umeå University.

Sörlin, S. (ed.) 2013. Nordic experience: science, geopolitics and culture in the Polar Region: Norden beyond borders (2nd edition). Farnham: Ashgate.

Tsing, A.L. 2003. Cultivating the wild: honey-hunting and forest management in southeast Kalimantan. In Zerner, C. (ed). Culture and the question of rights: forests, coasts, and seas in southeast Asia. Duke University Press. Pp. 24-55.

UNEP. 2011. Towards a green economy: pathways to sustainable development and poverty eradication. Arendal, Norway: UN Environmental Programme/GRID.

Wanner, T. 2015. The new 'passive revolution' of the green economy and growth discourse: maintaining the 'sustainable development' of neoliberal capitalism. New Political Economy 20(1): 21-41.

Wapner, P. 2011. Civil society and the emergent green economy. Review of Policy Research 28(5): 525-530.

Wells, M.P. and M.D. Williams. 1998. Russia's protected areas in transition: the impacts of perestroika, economic reform and the move towards democracy. Ambio 27(3): 198-206. 
West, P. 2006. Conservation is our government now: the politics of ecology in Papua New Guinea. Duke University Press.

West, P., J. Igoe, and D. Brockington. 2006. Parks and peoples: the social impact of protected areas. Annu. Rev. Anthropol. 35:251-277.

Wilson Rowe, E. 2013. A dangerous space? Unpacking state and media discourses on the Arctic. Polar Geography 36(3): 232-244.

Wilson Rowe, E. and H. Blakkisrud. 2014. A new kind of Arctic Power? Russia's policy discourses and diplomatic practices in the Circumpolar North. Geopolitics 19(1): 66-85.

Vitebsky, P. no year. The Arctic is... a Homeland. TheArcticls ...a web resource on the Arctic. Stefansson Arctic Institute.

Vladimirova, V.K. 2014. "It is not our reindeer but our politicians that are wild": contests over reindeer and categories in the Kola Peninsula, Northwestern Russia. Arctic Anthropology 51(1): 24-40.

Vladimirova, V.K. 2006. Just labor: labor ethic in a post-Soviet reindeer herding community. Uppsala: Uppsala Universitet.

Vladimirova, V.K. 2016. Nature conservation in Russia: the case of indigenous Sami Rights in the Kola Peninsula. In L. Elenius, C. Allard and C. Sandström (eds.) Indigenous rights in modern landscapes: nordic conservation regimes in global context. London: Routledge. Pp. 94-110.

Vladimirova, V.K. 2012. Transnational ethnic formations, European liberal multiculturalism and Russian narratives about indigenous separatism. Seminar in Multiculturalism in Russia. Uppsala Russian Study Centre, Uppsala University.

Vladimirova, V.K. 2011. "We are reindeer people, we come from reindeer": Reindeer herding in representations of the Sami in Russia. Acta Borealia 28(1): 89-113.

WWF. 2014. Hibiny spaseny/Hibiny has been saved. Available from http://www.wwf.ru/resources/news/article/11247. [Accessed 6 March 2017]

Zakharova, T. V. 2015. Zelenaya ekonomika i ustoychivoye razvitiye Rossii: protivorechiya i perspektivy [Green economy and sustainable development of Russia: contradictions and prospects]. Vestnik Tomskogo gosudarstvennogo universiteta. Ekonomika - Tomsk State University Journal of Economics 30(2):116-126. 